The ADB also has resident missions: in Bangladesh; Cambodia; China; New Delhi, India; Jakarta, Indonesia; Kazakhstan; Kyrgyzstan; Laos; Kathmandu, Nepal; Islamabad, Pakistan; the Philippines; Sri Lanka; Uzbekistan; Hanoi, Vietnam; and a regional mission in Port Vila, Vanuatu. There are also three representative offices: in Tokyo, Frankfurt and Washington, D.C.

Official language: English.

Headquarters: 6 ADB Avenue, Mandaluyong, Metro Manila, Philippines.

Website: http://www.adb.org

President: Tadao Chino (Japan).

\title{
ECONOMIC CO-OPERATION ORGANIZATION (ECO)
}

The Economic Co-operation Organization (ECO) is an intergovernmental regional organization established in 1985 by Iran, Pakistan and Turkey. ECO is the successor of the Regional Co-operation for Development (RCD) which was first established in 1964. ECO was later expanded in 1992 to include seven new members: Afghanistan, Azerbaijan, Kazakhstan, Kyrgyzstan, Tajikistan, Turkmenistan and Uzbekistan. The objectives of the organization, stipulated in its Charter, the Treaty of Izmir, include the promotion of conditions for sustained economic growth in the region. While transport and communications, trade and investment, and energy are the high priority areas in ECO's scheme of work, other fields of co-operation such as industry, agriculture, health, science and education, drug control and human development are also on the agenda.

While summit meetings lend reaffirmation of the high level commitment of ECO member states to the goals and objectives of the organization, the Council of Ministers (COM) remains the highest policy and decision-making body of the organization, which meets at least once a year and is chaired by rotation among the member states.

ECO Summits were instituted with the First Summit held in Tehran in 1992; the Second Summit was held in Istanbul in 1993, the Third in Islamabad in 1995, the Fourth in Ashgabat in 1996, the Fifth in Almaty in May 1999, the Sixth in Tehran in 2000 and the Seventh in Istanbul in 2002.

The long-term perspectives and priorities of ECO are defined in the form of two Action Plans: the Quetta Plan of Action, and the Istanbul Declaration and Economic Co-operation Strategy, which was adopted in 1996, with concrete targets to be achieved by 2005 .

The heads of state/government of the member states and the Council of Ministers have encouraged and endorsed the establishment of co-operative arrangements between ECO and major international and regional organizations and institutions within and outside the UN system for joint efforts towards implementation of ECO's economic projects and programmes.

ECO enjoys observer status with the United Nations, World Trade Organization and the Organization of Islamic Conference. A number of resolutions have been adopted in the UN General Assembly in the context of expansion of co-operation with ECO in the 1990s, most recently in Dec. 2001.

Headquarters: 1 Goulbou Alley, Kamranieh, PO Box 14155-6176, Tehran, Islamic Republic of Iran.

Website: http://www.ecosecretariat.org

e-mail: registry@ecosecretariat.org

Secretary-General: Askhat Orazbay (Kazakhstan). 